\title{
Editorial
}

\section{Trajetos clínicos e sociais em Saúde Bucal}

A presente edição especial em Saúde Bucal reúne artigos de pesquisa originais realizados por pesquisadores inseridos na gestão dos serviços públicos de saúde brasileiros, coordenadores de programas de pós-graduação e professores comprometidos com a pesquisa aplicada à clínica e em benefício da população, nos mais diferentes segmentos e especialidades.

Dentre os autores estão ainda alunos de programas de pós-graduação e de graduação, que estão construindo suas formações acadêmicas, com um olhar voltado a estudos que demostram a atual configuração da assistência odontológica no país, além da avaliação sobre o conhecimento de estudantes e professores sobre assuntos importantes para a formação acadêmica e ainda um olhar voltado à preocupação com a saúde de estudantes de Odontologia, Medicina e Enfermagem.

0 presente número é composto por 15 artigos, das quais 12 em Saúde Bucal, e que contemplam diferentes temáticas de interesse para gestores e estudiosos na área da saúde, em especial, da Odontologia, com diferentes metodologias, capazes de informar o leitor sobre resultados obtidos tanto em nível laboratorial, quanto nos grandes bancos dados com informações de saúde em nível nacional.

Outros temas também enriquecem a edição como comportamento sedentário, educação permanente e classificação de risco familiar.

Desejamos uma boa leitura a todos,

Isabella Lima Arrais Ribeiro

Cirurgiã Dentista. Mestre em Diagnóstico Bucal. Doutora em Modelos de Decisão e Saúde.

Pós Doutora em Epidemiologia.

Ricardo Dias de Castro

Cirurgião Dentista. Mestre em Odontologia Preventiva e Social. Doutor em Farmacologia. Pós-Doutor em Odontologia. Professor Adjunto do Departamento de Clínica e Odontologia Social da

Universidade Federal da Paraíba.

Editores convidados desta Edição 